\title{
Yavuz Sultan Selīm (1512-1520) and his imitation strategies
}

\section{A case study of four Ḥāfiz ghazals*}

\section{BENEDEK PÉRI}

\author{
Department of Turkic Studies, Eötvös Loránd University, Budapest \\ peri.benedek@btk.elte.hu
}

Received: July 01, 2018 • Accepted: November 01, 2019.

(C) 2020 The Author(s)

\section{ABSTRACT}

Unlike his Ottoman contemporaries, Yavuz Sultan Selìm composed his poems almost exclusively in Persian. A great part of his poetic output consists of poetic replies inspired by the classics of the Persian poetic canon as it was perceived by Ottomans. Through an in depth analysis of four imitation poems inspired by four ghazals by Hāfiz the present paper aims at highlighting the poetic strategies Selīm used when he composed poetic imitations.

\section{KEYWORDS}

Persian poetry, Persian literature, Ottoman poetry, Yavuz Sultan Selīm

\footnotetext{
* The present paper is a largely revised and enlarged version of my earlier article published only in Hungarian: 'I. Szelim szultán (1512-1520) imitációs technikája. Két Háfiz parafrázis példája', Keletkutatás 2016, tavasz: 63-76. It was conceived as part of a larger project aiming at the publication of a new critical edition of Sultan Selim's collection of poems (divan), which is hoped to appear in 2020.
} 
Yavuz Sultan Selīm composed poetry almost exclusively in Persian in a period when the imperial Persianate Ottoman literary paradigm and canon became firmly established and this new development led to a boom in the production of quality content in Turkish. ${ }^{1}$ It is no wonder that from the late $15^{\text {th }}$-early $16^{\text {th }}$ century onwards most Ottoman poets used Turkish as a literary medium and there were only a few who tried their hands at composing poetical pieces in Persian. Against this background Selīm's Persian poetry clearly deviates from contemporary Ottoman trends and it is not without reason to believe that Selīm's decision to write only in Persian was very consciously made. His poetic oeuvre seems to have been part of the Ottoman-Safavid propaganda war and it was supposedly meant to place Selīm into a Timurid cultural context, a common cultural heritage well-known to and even shared by the Ottomans and the Safavids and show his target audience, educated Persians in a flamboyant manner that Selim embodied the Timurid ideal of a sovereign who was a valiant warrior and at the same time a learned and highly cultured intellectual. ${ }^{2}$ A piece of visual evidence illustrating Selīm's ambitious goal appears at the most appropriate place, in a lavishly illustrated copy of his dìvān that is thought to have been prepared for the ruler himself (Ateş 1968: 466) in Khurasani style around 1515-1520 (Bağc1 and Çağman and Renda and Tanınd 2010: 61). The painting occupies a double page with one half portraying the Sultan as he sets off on a hunting expedition while the other half shows him sitting in the company of two young men listening to one of them reciting poetry from a book. There's another double folio in the volume that depicts hunting scenes with the Sultan hunting deer and fighting off the fierce attack of a lion at a hunting expedition (Dìvān-i Sulțān Selìm. FY 1330: ff. 27b-28a, 57b-58a.).

In classical poetry a seemingly easy way to demonstrate a poet's talent and skill in the art of poetry was to imitate popular or famous models. Imitation in Persianate ghazal poetry, especially in the form of a poetic reply (javāb) repeating the metre, rhyme and radif combination of a model poem is an acknowledged process of poetic creation that played an important role in the history of the Persian classical poetic tradition. Scholarly writings on the subject tend to treat this type of poetic imitation as a one-on-one poetic encounter in which an imitation poem keeps reflecting on and reacting to a previously composed poetic text. The imitation poem is viewed as a text which is in discourse with a single model and according to the technique chosen by the author it repeats or reuses poetic elements, key words, phrases, poetic images, and rhetoric figures of the model text in a slightly changed or a totally different poetic context.

An analysis of a great number of imitation ghazals, however, suggests that the process of composing an imitation of or a reply to a model ghazal tends to be of a more complex nature. When a number of poetic replies are inspired by a model, a set of paraphrases is established. Poems within a given set, besides being related to the model poem, are often inter-textually related to each other as well. The more poems there are in the set or the farther we get in time from the composition date of the original model, the possibility of such textual relations binding a freshly created text to its predecessor poems grows. If many of the paraphrases have connections to other poems within the set a paraphrase network is formed. ${ }^{3}$

Some paraphrase networks are short lived others, mainly those that are inspired by famous or popular poems, can have a long life spanning centuries and finally they can even turn into a ghazal sub-genre.

\footnotetext{
1 For a detailed description of the process see Kuru 2008.

2 For a detailed argumentation see Péri 2017.

3 For the concept of 'paraphrase network' in an Ottoman context see Péri 2018.
} 
A special feature of a paraphrase network is that the poems of the network share a mundus significance, a signifying universe that consists of characteristic, poetic contexts, ideas, images, key phrases and a set of rhyming words. The signifying universe of a paraphrase network can be compared to a heap of lego parts offering many possibilities for those who wish to build something from them. The parts and bits can be freely used according to the poet's aim and taste. He can freely choose from them and it is not compulsory to use them all. As time passes by the signifying universe of a paraphrase network necessarily grows and as authors of imitation poems composed at a later phase in the life of a paraphrase network have more choices, they begin using elements borrowed from other javābs within the set. These imitation poems, though they seem to be inspired by a single model, technically speaking, are replies inspired by the paraphrase network as a whole.

Composing poetic replies to earlier models became a very popular technique of artistic creation during the Timurid period the accomplishments of which served as a cultural model for creating the imperial Ottoman literary paradigm. This method was very consciously chosen among others by the founder of the Persianate Chaghatay literary tradition Mīr 'Alī-šīr Navāyī (d. 1501) who compiled a full collection (dīvān) of Persian poems containing mainly imitation poems or poetic replies (javābs) inspired by select texts of acknowledged authors (Navāyī 1342/1963; Zipoli 1993, Péri 2018). Yavuz Sultan Selīm seems to have followed in Navāyīs footsteps as according to Lațîīi (d. 1582), a $16^{\text {th }}$ century Ottoman literary critic, Sultan Selīm 'was most of the time imitating the dīvān of Navāyì (Latîfî 2000: 150). Since the greater part of Navāyī's poetic oeuvre was in Chaghatay Turkish and Selīm used almost exclusively Persian as a poetic medium, it is not without reason to believe that Lațifî̀s remark referred to Navāyīs collection of Persian poems.

It goes without saying that an imitation poem can have the desired effect only if it equals or surpasses its model in terms of artistic value. Quintilian, a Roman author of a much used manual on the art of rhetoric, advised his reader' to consult his own powers when he shoulders his burden. For there are some things which though capable of imitation may be beyond the capacity of any given individual, either because his natural gifts are insufficient or of a different character' (Butler 1920: 85). Quintilian's remark appears to have been valid in a Persian and Ottoman literary context as well where the success of an imitation also greatly depended on picking an appropriate model.

Selīm appears to have chosen his models very consciously, mainly from among celebrated authors of $13^{\text {th }}-15^{\text {th }}$ century Persian poetry and composed imitations modelled, among others, on ghazals by Sa'dī (d. 1291), Amīr Husrau (d. 1325), Salmān Sāvajī (d. 1396), Kamāl-i Hujandī (d. 1400), Kātibī Turšizì (d. 1434), Jāmī (d. 1492), Navāyī and last but not least Hạâiz (d. 1392). ${ }^{4}$

Ghazals composed by Hâfiz were often selected as models in the $15^{\text {th }}-16^{\text {th }}$ century (Yāršāțīr 1334/1955: 79-81) and a few Ottoman authors also tried their hands at composing javābs to them. Some of these were considered extremely bad by contemporary critics. 'Ahdī (d. 1593) mentions in his poetic anthology that a poet bearing the nom de plume Nisāaī who was able to versify in three languages, 'composed paraphrases to the complete Dīvān of Hăfiz' but he adds that 'I wish he had not written poetry in any language at all' (Solmaz 2005: 556). The imitation of Hāfiz’'s ghazals was considered very close to a mission impossible and all efforts spent on such an endeavour futile because as Ḳınalızāde Hasan Çelebi (d. 1604), another Ottoman biographer from the $16^{\text {th }}$ century, put it 'Since Master Hāfiz-i Šīrāzīs eloquent verses were inspired by the sa-

${ }^{4}$ For poets imitated by Selīm see Péri 2010, 2015a, 2015 b. 
cred spirit they are without any unnecessary circumstantialities and blemish. They might as well be directly translated from the words of the Invisible. Any effort at composing javābs to this kind of pure poetry thus falls very far from the right path' (Kinalızade 1989: 753).

The present paper is going to provide the reader with an analysis of four imitation ghazals composed by Selìm, two of which have been recently found during the ongoing process of preparing a new critical edition of Selīm's dìvān. Through analysing Selīm’s javābs inspired by Hāfiz’s famous first ghazal, his poem starting with the words 'Agar ān turk-i šìrāzì ('If that Turk from Shiraz'), and two lesser known ghazals, it aims at examining how Selim fared on the field of imitating famous and less popular pieces by an acknowledged poet and at the same time it tries to showcase the basic strategies Selìm used to build up his Hāfiz imitations.

The first ghazal of the dìvān of Hāfiz became a very popular model for imitation during the Timurid period and by the end of the $15^{\text {th }}$ century a well-defined 'Hāfiz's first ghazal' paraphrase network and a shared mundus significans (signifying universe) evolved. The javābs of Kātibī, Fattāḥī (d. 1448), Amīr Šāhī (d. 1453), Jāmī, Navāyī, Qabūlī (fl. 15 $5^{\text {th }}$ century), La'ālī (fl. late $15^{\text {th }}$

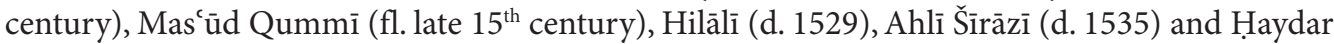
Haravi (d. 1552), were linked to their model as well as to each other through an intricate network of inter-textual links. ${ }^{5}$ Since many outstanding and significant authors of the age composed poetic responses to the first ghazal of Hāfiz, an acknowledged and thus successful javāb might have paved the way for a daring, ambitious and talented poet into an exclusive circle of the literary elite. Poetic responses to Hāfiz̧'s first ghazal are often met with in dīvāns from the first half of the $15^{\text {th }}$ century onwards, which also indicates that poetic replies to the first ghazal of Haafiz evolved into a popular subgenre within classical ghazal poetry.

Selīm, who besides having success on the battlefields quite evidently aspired to win poetic laurels, could not resist the challenge represented by such an emblematic model and composed a poetic response to it. ${ }^{6}$ We do not have an autograph but in the illustrated manuscript previously

5 See Kātibī 1382/2003: 23; Fattāhịi 1385/2006: 1; Šāhī 1348/1969: 1; Jāmī 1378/1999, 1: 194-195, 2: 79-82, 468-469; Navāyī 1342/1963: 68-69; Ertaylan: 1948, rrrr; La’ālī, f. 236a; Sup: 1995, V; Hilālì: 1338/1959, 15; Ahlī: 1344/1965: 4; Haydar Haravī: f. 6b.

6 Selim's imitation is contained in almost all the manuscripts used for the critical edition: Millet Genel Kütüphanesi AE Farsça 324, ff. 18a-b (AE); Amasya Bayezit Il Halk Kütüphanesi 486, f. 3a (Amasya); Süleymaniye Yazma Eser Kütüphanesi Atıf Efendi Koleksiyonu 2077, f. 3b (Atif2077); Süleymaniye Yazma Eser Kütüphanesi Atıf Efendi Koleksiyonu 2078, ff. 15a-b (Atif2078); Süleymaniye Yazme Eser Kütüphanesi Esad Efendi 3422, f. 2b (Esad); Süleymaniye Yazma Eser Kütüphanesi Fatih 3830, ff. 3b-4a (Fatih); Süleymaniye Yazma Eser Kütüphanesi Hac1 Mahmut Efendi 3630, ff. 14b-15a (HM); İstanbul Üniversitesi Nadir Eserler Kütüphanesi FY 929, f. 17b (IU929); İstanbul Üniversitesi Nadir Eserler Kütüphanesi FY, 1016 f. 6 b (IU1016); İstanbul Üniversitesi Nadir Eserler Kütüphanesi FY1067 f. 11a (IU1067); İstanbul Üniversitesi Nadir Eserler Kütüphanesi FY 1330, ff. 5b-6a (IU1330); İstanbul Üniversitesi Nadir Eserler Kütüphanesi FY 1331, ff. 23a-b (IU1331); Süleymaniye Yazma Eser Kütüphanesi Lala İsmail 449, ff. 4a-b (LI); Kitābhāna, Mūza va Markaz-i Asnād-i Majlis-i Šūrā-yi Islāmī 13392, f. 1b (Majlis13392); Kitābhāna, Mūza va Markaz-i Asnād-i Majlis-i Šūrā-yi Islāmī 21013 pp. $101-102$ (Majlis21013); Sāzmān-i Asnād va Kitābhāna-yi Millī no. 814721, pp. 5-6 (Millī); Süleymaniye Yazma Eser Kütüphanesi Nuruosmaniye 3827, ff. 5a-b (NO); Süleymaniye Yazma Eser Kütüphanesi Reşid Efendi 762, f. 4b (RE); Topkapı Sarayı Müzesi Yazma Eserler Kütüphanesi Revan 507, f. 5a (Revan507); Topkapı Sarayı Müzesi Yazma Eserler Kütüphanesi Revan 737, f. 6b (Revan737); Topkapı Sarayı Müzesi Yazma Eserler Kütüphanesi Revan 738,f. 4a (Revan738). The poem is missing from two of the manuscripts: National Library of Israel Yahuda Collection Ar. 1128 (Jerusalem), Kitābhāna va Mūza-yi Millī-yi Malik 4620 (Malek). They might have been written on folios missing from these manuscripts. The poem also appears in Paul Horn's edition Selīm 1904, 22. 
mentioned it is the first poem in the gazalìyat section. ${ }^{7}$ This significant place allotted to the poem in this manuscript seems to suggest that Selim was satisfied with the result of his poetic efforts.
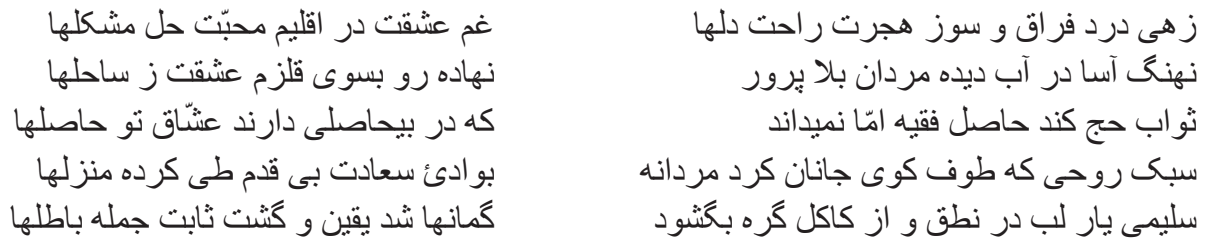

Even a superficial reading of Selīm's ghazal is enough to notice that except for a few compulsory formal elements such as the metre, rhyme and radif combination and a few shared rhyming words (dil 'heart', muškil 'difficult', sāhil 'shore' and manzil 'station') the model and its imitation have very little in common. Not even the number of couplets is the same (Hāfiz: 1382/2003, 75). While Hăfiż's poem and most elements of the 'Hāfiz first ghazal' paraphrase network consist of seven couplets, Selīm's javāb consists of only five which is quite uncharacteristic of the sultan's ghazal poetry as a great number of his ghazals consist of seven or nine bayts.

A further essential formal difference between the model and its imitation lies in the fact that though the ghazal of Hāfiz starts and finishes with Arabic lines, Selīm, like Šāhī, Kātibī and Ahlī before him ignored this emblematic feature of the model poem repeated in most of the poetic replies. It is difficult to tell exactly why Selīm decided not to add Arabic verses to his poem but if the most famous Ottoman commentator of Hāfiẓ, Sūdī Bosnavì (d. 1599?) was right in asserting that poets with Shiite inclination resented the lines in the model poem that contemporary literary criticism attributes to Yazīd ibn Mu'avìya (d. 683), the Umayyad caliph whose army was responsible for massacring the Shiite martyrs of Kerbala in 680, Selīm's decision might have something to do with the religious sentiments of Iranian intellectuals, his targeted audience (Brockhaus 1854: 2).

As far as its content is concerned, out of the two key topics of Hāfiz's ghazal, wine and love, Selim retained only the latter one. Wine, wine consumption and intoxication be it in its real or a metaphorical sense are not often recurring motifs in Selim's ghazals, so the omission of the topic of wine from his imitation poem fits into the general pattern of his ghazals very well.

The poem in Selim's version is about a painful relationship. Love is the topic that connects the first three couplets. The semantic field of a religious Muslim's visit to the Ka'ba connects the fourth couplet to the previous one where the term for pilgrimage, hajj, occurs. These two couplets elevate the poet's emotions into celestial heights and suggest that his love is not ephemeral human love ('ašq-i majāzi $)$ but an eternal love directed towards the Supreme Being ('ašq-i haqqīqu). The last bayt, the maqta' which makes it clear that the sultan's beloved is a human being, is logically not connected to the preceding couplets in any way and makes the reader feel as if the only reason for its being there is the rhyming word bāțil 'rumour' Selīm was determined to use.

In the case of an imitation or emulation poem one would expect to find at least a few inter-textual allusions to its supposed model but in Selīm's ghazal there are none. However, when Selim's ghazal is compared to the whole set of poems of the 'Hāfiz's first ghazal' paraphrase network it

\footnotetext{
7 The ghazal is placed first in the following manuscripts: İstanbul Üniversitesi Nadir Eserler Kütüphanesi IU1016, IU1330, Milli, Fatih, Revan737, Revan738. It is placed second in the following manuscripts: Majlis13392, Atif2077, Esad, LI, NO, RE, Revan507.
} 
is not difficult to realize that its five couplets are full of allusions linking Selim's piece to earlier poetic texts.

The second hemistich of the first couplet closes with the noun phrase hall-i muškil-hā'a solution for all troubles' which is one of the emblematic expressions of the 'Hāfiż's first ghazal' network used by Šāhī, Kātibì, Ahlī, and last but not least by Jāmī who applied it in three out of his seven javābs.

Selīm's exquisitely elegant and graceful second bayt which is a telling example of the poet's creative talent and imagination also shows how closely connected Selim's piece is to other poems of the 'Hāfiz's first ghazal' tradition, as the source of inspiration for the second couplet seems to have been the fourth couplet of Kātibī's ghazal.

\section{Selīm II.}

Nahang-āsā dar-āb-i dìda mardān-i balā-parvar

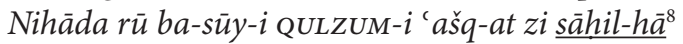

In their tears miserable men, like crocodiles

Turned their faces towards the ocean of your love from the shores.

\section{Kātibī IV.}

Dar īn DARYĀ ki kam-tar qatra-aš tì̀ ast ġavši kun

Ki sar-hā-yi nahang-ān-i bì-badan bìnì bi-sāhil-hāa

Dive into this ocean where even the smallest drop is a sword,

When you see the headless bodies of crocodiles on the shores.

Though the poetic context and the metaphors dominating the two couplets are different, the joint occurrence of two key elements, the image of crocodiles (nahang) which is present only in Kătibī's javāb and the rhyme word sāhil ('shore') cannot be coincidental. If we add that some of Kātibī's ghazals served as models for Selīm, the connection between the two javābs seems to be firmly established. ${ }^{9}$ The similarities between Selīm's third and Navāyī's fifth couplet does not appear to be coincidental either.

Selīm III.

Șavāb-i haj KUNAD HĀṢIL faqīh ammā na-mī-dānad

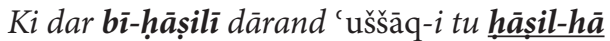

A jurist harvests the fruit of reward for completing a pilgrimage but he doesn't know

That these fruits are useless in the eyes of your lovers.

Navāyī V.

Man u bī-ḥāṣilī ki-z ${ }^{c} i l m$ u zuhd-am ān či HĀSSIL ŠUD

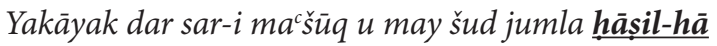

Me and the uselessness of all that I've harvested from learning and austerity,

All the things I had harvested were spent on my beloved and wine.

8 Typographic devices are meant to highlight the parallelisms of the couplets compared.

9 For Selīm's ghazals modeled on Kātibī’s poems see Péri 2010: 28, 33. 
The dichotomy of useless orthodox religious practices taking the devotee nowhere closer to his goal and the mystic's successful spiritual quest facilitated by love or wine, a recurring topos in classical ghazal poetry is the basic idea behind both couplets which is expressed by both Navāyī and Selìm in a very similar way, using the same or very similar tropes, words and phrases. The parallelisms between the two bayts, the pair of opposing notions of fruitful ( $h \bar{a} s i l)$ and fruitless

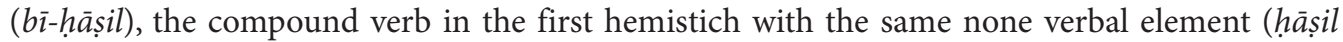
kunad; hạssil šud ) that serves to secure a poetic focus on the concept of 'fruitfulness', the antithesis of orthodox religion represented by the character of a jurist ( $f a q i h)$ in Selìm's ghazal and by the term 'asceticism' (zuhd) in Navāyī's poem and the mystical path symbolized by lovers and beloved respectively, the appearance of two verbal nouns ('ušša $\bar{a} q$ 'lovers'/ma'š $\bar{u} q$ 'beloved') formed from the same Arabic radicals and last but not least the use of the same rhyming word seems to confirm the reader's suspicion that the basic idea for Selīm's couplet came from Navāyìs bayt.

The inspiration for Selīm's next couplet seems to have come from a third javāb of the 'Hāfiżs first ghazal' paraphrase network.

\section{Selim III.}

Sabuk-rūḥ̄ ki țauf-i kūy-i jānān kard mardāna

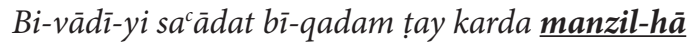

A light-hearted one who bravely circumambulated the street of his beloved,

Travelled through all the stations in the valley of bliss without taking a single step.

The poetic mixture of the idea that pilgrimage, let it be a religious one or a visit to the street where the poet's beloved dwells, is a spiritual rather than a physical journey, the presence of the semantic field of hajj represented here by the term (tauf'circumambulate'), the occurrence of the word $r \bar{u} h$ ('soul') and the presence of the noun manzil ('station') as the rhyming word within one couplet might all be interpreted as hints pointing to the direction of a possible model, the third couplet from the first of Jāmīss seven javābs.

Jāmī 1/III.

Bi-jān šau sākin-i Kacba biyābān čand paymāȳi

Ču nabvad qurb-i rūḥānī či sūd az qat'-i manzil-hä

You should dwell in the Kacba in your heart. Why are you treading through the desert?

If spirituality is not close to you, travelling through the stations does not make any sense.

The inter-textual links connecting Selīm's poem to the javābs of Kātibī, Navāyī and Jāmī highlight Selim's cunning strategy of imitating the first ghazal of Hāfiz. Instead of risking a failure and a bad poem by trying to compose a direct response to his supposed model, in other words by trying to imitate the inimitable, he found a way round his problem. He turned to the poems of the 'Hāfiz̧s first ghazal' network instead that by his time had developed into a 'Hāfiẓ's first ghazal' tradition, picked and reworked several elements of its signifying universe and from these poetic building stones he built up his own javāb.

When Selim set to compose one of his other javābs that at first sight seems to be a poetic response to another ghazal by Hāfiz, he chose a slightly different strategy. Before we go into details we should have a short look at the supposed model, Hāfiz's ghazal starting with the words Agar ān turk-i šìrāzī.. 'If that Turk from Shiraz...' 
Though it is one of, if not the most analyzed of his poetic pieces subjected to many scholarly attempts of interpretation by literary critics in the $20^{\text {th }}$ century (Hilmann 1975: 164), it has hardly ever been stressed that Hāfiż's poem itself is part of an intricate network of javābs that possibly started with two long ghazals by Rūmī (d. 1273) (Rūmī 1388/2009: 99-100, 109). The network consists of three intertwined sets of poems relying on the same rhyme $(-\bar{a})$ and $\operatorname{rad} \bar{f} f(-\bar{a})$ but different metres. One group of poems is in mujtass-i musamman-i mahbūn-i mahzuüf(. - . - . . - - | .- . - | - - or ..-), a second group uses the metre hazaj-i musamman-i sālim (. - - | . - - | . - - | . - ) and the third group is in ramal-i musamman-i mahbün (- .- or ..- - . .- - ..- - ..--). ${ }^{10}$ The two latter branches were started by Sa ${ }^{c} \mathrm{di}$ (d. 1292) whose four poems, two in mujtass, one in ramal and one in hazaj became quite fashionable models for oncoming generations of poets ( $\mathrm{Sa}$ ' $\mathrm{di}$ 1385/2006: 523, 524, 1050). The hazaj branch of the network is represented among others by the poems of Amīr Husrau, Salmān Sāvajī, Ḥāfiẓ, Šāhī, Mag̉ribī (d. ca. 1408), Kātibī, Fattāhīi Qārī-yi Yazdī (fl. $15^{\text {th }}$ c.), Abū Ishāq (fl. $15^{\text {th }}$ c.), Jāmī, Navāyī, Āhī (fl. $15^{\text {th }}$ century) and Hilālī. ${ }^{11}$ The mujtas $\underline{s}$ branch consists of javābs by Amīr Husrau, Nizārī Quhistānī (d. 1320), Ḥāiụ, Mag̉ribī, Kamāl-i Hujandī, Jāmī, Navāyī and Ahlī Šìrāzì. ${ }^{12}$ The ramal group includes javābs by Hasan-i Dihlavī (d. 1337), Salmān Sāvajī, Kamāl-i Hujuandī, Ašraf, Humāyūn Isfaraynī (d. 1496) and Jāmī. ${ }^{13}$ The most striking feature of the three sets of javābs is that though they rely on different metres they seem to share the same mundus significans, the same signifying universe. Metaphors and other rhetoric devices, motifs, rhyming words, key concepts seem to have been interchangeable between the sets. Ideas used by one poet in a ghazal written in mujtass might appear in a later javāb by another author composed in hazaj or in ramal. The names of the two Central Asian cities, Samarkand and Bukhara at the end of the famous first couplet of Hāfiz, for example, first occur together in a ghazal composed in mujtass by Amīr Husrau ${ }^{14}$ and the rhyming phrase of the third bayt in the ghazal of Hāfiz (hān-i yağmāa is first used by $S^{c}{ }^{c} \overline{1}$ in a context very similar to the one we see in the couplet of Hāfiz, in one of his ghazals also composed in mujtass.

\section{Husrau III.}

Nașīb-i husn girift ān but-i Samarqandī

$\check{C} u$ kišvar-i dil-i mā hițța-yi Buhārāa-rā

The fame of that idol from Samarkand,

Conquered the country of our heart like the land of Bukhārā.

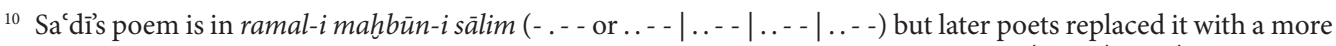
frequently used ramal metre, ramal-i musamman-i makhbūn-i maḥzūf (- . - or . . - | . - - | . - - . . - or - -).

11 For the texts see Amīr Husrau Dihlavī 1361/1982: 4; Salmān Sāvajī 1371/1992: 366-367; Hāfiz 1382/2003: 7576; Šāhī 1348/1969: 2; Mag̉ribī 1372/1993: 9, 11; Kātibī 1382/2003: 21-22; Fattāhī 1385/2006: 4-5; Qārī-i Yazdī 1303/1886, 37; Abū Ishāq 1302/1885: 31; Jāmī 1378/1999: 1:470-371; Navāyī 1342/1963: 72-73; Āhī: f. 139a; Hilālī 1338/1959: 2;

12 Amīr Husrau Dihlavī 1361/1982: 18-19; Nizārī Quhistānī 1371/1992: 496-497; Hāfiz 1382/2003: 76; Mag̉ribī 1372/1993: 21; Kamāl-i Hujandī 1372/1993: 26; Jāmī 1378/1999: 1:198, 200, 2:83, 484-485; Navāyī 1342/1963: 78 Ahlī: 1344/1965: 10-13.

13 Hasan Dihlavī 1383/2004: 4; Dīvān-i Kamāl-i Hujandī,26; Dīvān-i Ašraf. Süleymaniye Yazma Eser Kütüphanesi, Fatih 3777, f. 4b; Jāmī 1378/1999: 1:198-199.

14 Buhārā as a rhyming word occurs first in a ghazal composed in mujtass by Nizārī Quhistānī. Nizārī Quhistānī 1371/1992: 496-497. 
Sacīi X.

Tu ham-čunān dil-i šahrī bi-gamza-ī bi-barī

Ki bandagān-i banī Sa'd hān-i yag̀mā-rā

You rob the hearts [of the inhabitants] of a whole city with a wink, the same way,

Like adherents of the Banu Sa'd when they take spoils.

The ghazal of Hāfiz composed in hazaj, he also wrote a poem in mujtass, is an important milestone in the history of the ' $-\bar{a}-r \bar{a}$ ' javāb network as it exerted a great influence on ghazals belonging to the ' $-\bar{a}$-ra $\vec{a}$ tradition from the $15^{\text {th }}$ century onwards and it inspired many poets to compose poetic replies to it. Let it suffice to mention the imitation poems of Qārī-i Yazdī, Abū Ishāq and Asrārī (another tahalluṣ used by Yahyā Sībak 'Fattāhị̂) that were all composed as lampoons and the poetic replies of Navāyī and Jāmī. It should be added here that eight further ' $-\bar{a}-r \bar{a}$ ' ghazals composed in hazaj are known from the post-Hāfiz period but they were not necessarily meant as direct poetic responses to the ghazal of Hăfiz.

The analysis of Selim's ghazal should be done against this literary background with a view to the above described poetic context and the comparative research should include all the poems of the ' $-\bar{a}-r \bar{a}$ ' network of javābs.
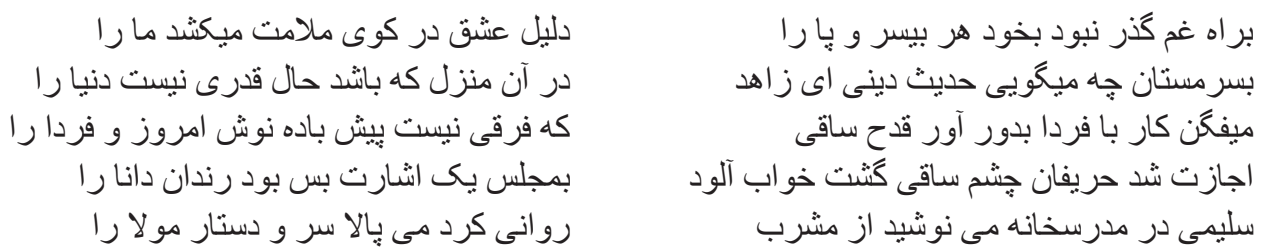

Selim's ghazal is in hazaj and it consists of five couplets. ${ }^{15}$ Two main topics dominate the poem: love and more importantly wine and wine drinking, which is very atypical of Selim's ghazals. Though key subjects and the main heroes, the sāqi 'cupbearer' and the drunkards lend a very Hafizian atmosphere to the poem, inter-textual allusions scattered throughout the text of the poem, however, suggest that some of the couplets were inspired by other poets' $-\bar{a}-r \vec{a}$ ' ghazals.

The mațla' seems to resemble the first bayt of Šāhîs response to Sa'dỉ’s ghazal.

Selìm I.

Bi-rāh-i gam guzar nabvad bi-hud har bì-sar u pā-rä

Dalìl-i cašq dar kūy-i malāmat $M \bar{I}-K A \check{S} A D M \bar{A}-R \bar{A}$

Not every miserable person walk go on the road of affliction on his own,

A sign of love draws us to the street of scorn.

Šāhī I.

Bi-hud rah nīst dar kūy-i tu muštāqān-i šaydā-rāa

Hum-i zulfat bi-qullāb-i muhabbat $M \bar{I}-K A S ̌ A D ~ M \bar{A}-R \bar{A}$

15 The poem is included in the following manuscripts: AE f. 24b; Amasya f. 2a; Atif2078 f. 20b; Fatih f. 9a; HM f. 19a; IU929 f. 16a; IU1330 f. 11a; IU1331 f. 28b; Majlis13392 f. 6a; Milli p. 16; NO f. 13a-b; RE f. 10b; Revan738 f. $9 b$. 
Lovers mad with desire cannot enter your street on their own,

Your curly locks, the hooks of love, draw us there.

The method Selīm used to imitate Šāhī’s first mișrā' is one of the basic techniques of creating a close replica of a chosen model. The key elements of the model line are either retained as it happens in the case of the phrase bi-hud 'on his own' or they are replaced with synonymous or near synonymous expressions. Selìm replaced the phrase rah nīst ('there is no way') with guzar na-buvad ('there is no passage'), the noun phrase muštāqān-i šaydā ('people who are mad with desire') with har bi-sar $u$ pa ('every powerless one') and the phrase dar kīy-i tu ('in your street') with $b i$-rah-i gam ('to the road of sorrow') which all might be interpreted as synonyms of each other in the context of lyric ('āšiqāna) ghazal poetry.

Selim's strategy for composing his second bayt was somewhat different and thus the result is not a close replica but more of an emulation evoking the sixth couplet of Sa'dìs ghazal:

Selim II.

Bi-sarmastān či mì-gūyì hadīs $\underline{-} i$ dìn̄i ay zāhid

Dar ān manzil ki bāšad ḥāl QADRĪ NĪST dunyā-rāa

Ascetic, why are you trying to talk about religious tradition to the intoxicated ones,

In a house where ecstasy rules, people do not care for this-worldly matters.

Sa'dī VI.

Murād-i mā viṣāl-i tu-st az dunyā u az 'uqbā

Va gar na bì-šumā QADRĪ NA-DĀRAD dīn U dunyā-rā

Our only desire in this world and the next one is to be with you,

If it does not come true, religion and worldly matters do not have any value for us.

Selīm seems to have been inspired by the core idea expressed in Sa'dỉ's couplet: those who are truly intoxicated by love, are overwhelmed by their emotions so much that they do not care for this-worldly matters like material goods or orthodox religious practices. While Selim slightly reworked the topic through shifting the focus of the couplet more towards stressing the dichotomy of the mystical spiritual experience and orthodox religious practices he labelled this-worldly, he retained the rhyming word and several of the key words and phrases present in the model couplet, like $\operatorname{din}$ ('religion') and qadrī nīst ('it does not have any value'). Through the new poetic context he created by introducing the opposing pair of the 'intoxicated ones' (sarmastān) and the 'ascetic' (zähid), an antithesis often met with in the ghazals of Hāfiz, he manages to give a very Hāfizian touch to his emulation of Sa'dī's bayt.

Though the basic idea of Selim's third couplet that we should live in the present and cherish every moment of it because the future is insecure and shaky also comes from Sacdìs ghazal, the wording of the couplet, the inclusion of the phrase $b \bar{a}$ fard $\bar{a}$ ('with tomorrow') and the rhyming word fard $\bar{a}$ ('tomorrow') within the same bayt suggests that besides being inspired by Sac dì, Selīm was also influenced by Šāhī’s fourth bayt. The Sa'dī-Šāhī poetic mixture received a very Hafizian flavouring through adding the character of the cup-bearer $(s \bar{a} q \bar{\imath})$ and the wine drinking poet who calls out to the $s \bar{a} q \bar{\imath}$ to bring more wine because this intoxicating substance helps him to reach an ecstatic state of mind where this-worldly matters such as time do not count any more. 
Selim III.

Ma-yafgan kār $\underline{B \bar{A}}$ FARDĀ bi-daur āvar qadah sāqi

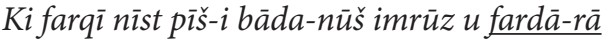

Do not worry about tomorrow! Sāqī give the cup around!

Because for someone who drinks wine the difference between today and tomorrow doesn't exist.

Šāhī IV.

Ġam-i nā-āmada hurdan bi-naqd-am ranja mì-dārad

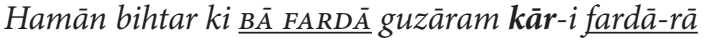

Worrying about problems that have not arrived yet would unnecessarily burden my soul,

It is much better if I left tomorrow's problems to tomorrow.

Sa'dī VIII.

Bi-yā tā yak zamān imrūz huš bāš̄im dar halvat

Ki dar 'ālam na-mì-dānad kasī ahviāl-i fardā-rā

Come and let's have a good time today, only you and me alone,

Because nobody in this world knows what tomorrow will bring.

The analysis of Selīm's '- $\bar{a}-r \bar{a}$ ' ghazal suggests that Selìm very consciously tried to avoid the inclusion of direct textual allusions to the ghazal of Hāfiz and except for a very vague hint at the end of the fourth couplet where the phrase containing the rhyming word and the radif rinda $n-i$ $d \bar{a} n \bar{a}-r \bar{a}$ ('for the wise drunkards') evokes the image of the wise old man, another character from the tavern whose advice the blessed young people cherish in the seventh couplet of the '- $\bar{a}-r \bar{a}$ ' ghazal of Hāfiz, he succeeded in his efforts. Though at a first glance Selim's poem seems to be a poetic reply to the ghazal of Hâfiz, in reality it is an imitation poem inspired by the whole of the '- $\bar{a}-r \bar{a}$ ' paraphrase network. Selim used the poetically rich mundus significans of classical poetry focusing his attention on elements available in the signifying universe of the evolving ' $-\bar{a}-r \bar{a}$ ' subgenre and like a kid playing with legos, he used choice elements of the set available to him to build an original poem which is in constant discourse with previous poems of the ' $-\bar{a}-r \vec{a}$ ' network. He

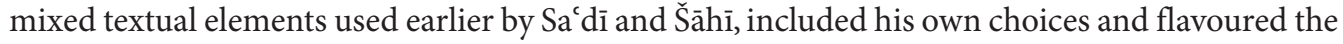
mixture with the topic of wine-drinking, a topic introduced by Hāfiz to the ' $-\bar{a}-r \bar{a}$ ' javāb network. In this way he could join the distinguished company of acknowledged poets like Navāyī and Jāmī who composed successful poetic replies to the ghazal of Hăfiz and at the same time he could successfully avoid having to cope with the difficulties the imitation of a famous and practically inimitable poem presented.

The third and fourth poems were selected to show how Selim imitated a model when it was a relatively lesser known ghazal. There are common features both imitation poems share: neither of them has been published yet, both of them are contained in the same group of manuscripts, both of them belong to relatively small paraphrase networks, the initial poems of the two networks were written well-before Hāfiz, both models were originally panegyrics and neither of them were written in ghazal form.

The imitation poem composed in hazaj-i musamman-i ahrab-i makfüf-i mahızūff ( - - . . - - . | . - . . . - ) using the rhyme -ištī has an additional feature. It contains a hint that makes at least an approximate dating possible which is quite rare in the case of lyric ghazals. The appearance of the 
place name Trabzon in the first couplet suggests that the ghazal was composed during Selim's stay in the city. He was seventeen when he was appointed governor in 1487 and he remained posted to the city until 1510 so this ghazal might have been composed during this period. ${ }^{16}$
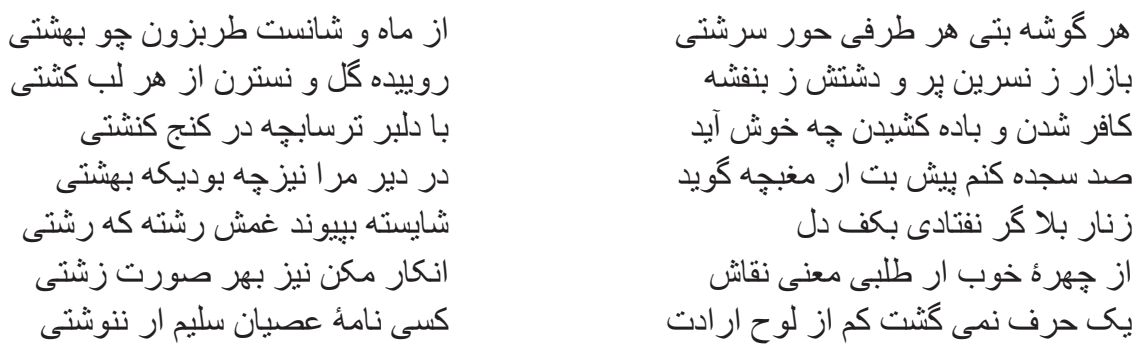

The initial poem of the paraphrase network is a qasida by the well-known Ismaili poet Nāṣir-i Husrau (d. ca. 1077) possibly addressed to a local dignitary in Khurasan (Nāṣir-i Husrau 1357/1978: 365-366). Though qasidas in most cases aim at praising the addressee and extol his virtues, Nāșir-i Husrau's poem keeps blaming the person he addresses and the poem is full of reproach. As far as its tone and wording is concerned it resembles a love poem, an 'äšiqāna ghazal rather than a qasida. Perhaps it was this feature that caught the attention of Sa'di who saw the poetic potential in the text and composed a poetic reply to it. Though Sa'dī wrote his poem in the form of a lyric ghazal he retained both the formal framework represented by the metre, rhyme and radif combination and the reproaching, moralising tone (Sa'di 1385/2006: 859). The next poem in the paraphrase network composed in the same mood is a ghazal by Auhadi (d. 1338) (Auhadī 1376/1997: 365) that was followed by a ghazal composed by Hāfiz (Hāfiz 1382/2003: 278). Hāfiz's poem represents a milestone in the history of the paraphrase network from two essential points of view. First because Hāfiz introduced a new motif, wine, and secondly because he slightly changed the rhyme. While earlier the rhyme was -šti as Nāșir-i Husrau, Sa 'dī and Auhadī also used words like guzašt $\bar{\imath}$ 'you've left' bi-kušti 'you've killed', duruštī 'coarseness' as rhyming words, Hāfiz narrowed the range of rhyming words and applied only those of the original set that have a penultimate front vowel (na-nivištī 'you haven't written', na-kišti 'you haven't sown', etc.). The poem of Hāfiz became a model for an Ottoman poet of Mehmed II's reign (1444-1446, 1451-1481), Hāmidī (d. after 1488) who saw so much poetic potential in Hāfiẓ’s ghazal that he composed three poetic replies to it (Ertaylan 1949: 507-508).

Selim followed in the footsteps of his Ottoman predecessor in the sense that his poem was clearly also meant as a reply to the ghazal of Hāfiz. It should be stressed however, that the version of the poem of Hāfiz Selimm imitated was slightly different from the poem found in modern editions because the ghazal in the Ottoman Hāfiz tradition included a few additional couplets. ${ }^{17}$ Selīm's javāb does not contain any direct inter-textual references to Hāfiż's ghazal; still the choice of rhyming words and motifs characteristic of the poetry of Hāfiz create an atmosphere that evokes the mood and tone of the model poem very well. However, when it comes to details, it

16 The poem is contained in the following manuscripts: AE f. 75b; Amasya f. 43b; Atif2078 f. 64b; HM f. 64a; IU929 f. 52b; IU1067 f. 47b; Jerusalem ff. 65a-b; Majlis13392 f. 52a; Majlis21013 pp. 199-200.

17 Sūdî̀s commentary contains thirteen couplets, five more than the version in the critical edition (Sūdī 1366/1987: 4: 2346-2352). 
seems that Selīm relied on other poems of the paraphrase networks as well and borrowed elements of their mundus significans. Selīm's first couplet with the rhyming phrases, hū r-sirištī houri natured' and ču bihišti 'like a heaven' appear in the same order in the first couplet of Hāmidīs second poem. The syntactic arrangement of the first hemistich with two phrases covering almost the same metrical space connected by an $u$ 'and' in one case and a 'comma' in the other and the appearance of the word butī 'a beauty' and the noun phrase hùur-sirišti within the same mișrā' suggest that Selīm was aware of Sa'dī's poem.

Selīm Ia

Har gūšsa butī, har țarafī ḥūr-sirištī

'An idol in every corner, a houri-natured one in every direction...'

Sa'dī VIIIb

Sarvī saman-andām u butī ḥūr-sirištì

'A jasmin bodied cypress and a houri-natured one...'

The closing couplet of the two poems also contain parallelisms as three key concepts, all present in Sa'dī’s fist hemistich, re-appear in Selīm's first mișrā' .

Selīm VII.

Yak harf NA-Mī-GAŠT kam az lauh-i irädat

Kasī nāma-yi 'ișyān-i Salìm ar na-nivištī

Not a single letter would have disappeared from the paper of God's will,

If someone hadn't written a report on Selīm's disobedience.

Sa ${ }^{c}$ dì X.

Saylāb-i qażā NA-STARAD az daftar-i ayyām

In-hā ki tu bar hāttir-i Sa'dì bi-nivišti

The flood of God's will hasn't deleted from the copy book of fate,

Those [things] that you wrote there for Sa' dì.

The notion of qażā meaning God's will that decides all created beings' fate in Sa'dīs poem appears through the word irādat 'will' in Selimm's. The concept of a surface containing the will of God in a written form is represented by the noun daftar 'copy book' in Sa'dīs couplet and by the word lauh 'a sheet of paper' in Selimm's bayt. The verb na-starad 'doesn't delete' conveys the idea of a process that leads to the deletion of some parts of a written text in Sa'di's poem and so does the verb phrase yak harf kam na-gašt 'not a single letter has disappeared' in Selim's first line. The fact that the parallelisms occur in a couplet that has the verb nivišt 'wrote' as the rhyming word seems to further confirm the theory that in the case of the last couplet Selīm was heavily influenced by Sa'dī's bayt. However, some key motifs of Selīm's maqta', including the past conditional expressing an unreal condition, the motif of the surface containing a written text, the presence of the noun nàma 'letter', the concept of heavenly will are elements also found in Hăfiz's poem. 


\section{Hāāiz I.}

$\bar{A} n$ ġäliya-hat gar sūy-i mā nāma nivištì

Gardūn varaq-i hastī-yi mä dar na-nivišti

If that person with fragrant peach fuzz hadn't written a letter to us,

The Sky wouldn't have crossed out [the writing on] the page of our existence.

Except for these intertextual hints hidden in the first hemistich and the last couplet and the set of rhyming words used, Selim did not include further textual allusions to any of the poems constituting the paraphrase network. The lack of a radif that could confine a poet into a narrow poetical space, the diversity of semantic fields defined by the set of rhyming words and the flexibility of the poetic moods present in the poems of the paraphrase network created a vast poetical playground for Selim and made it possible for him to freely choose from the wide range of poetic elements available in the mundus significans of the literary tradition. The result is an emulation poem composed in awareness of the existence of other poems within the '-šti paraphrase network' Through a special focus given to poetic features characteristic of the poetry of Hăfiz this poetic reply inspired by the whole of the network receives a very Ḥăfizian tint.

The fourth poem chosen for analysis is also part of a relatively small paraphrase network and it has not been published yet either. The poem is composed in the metre mużärici $i$ musamman-i ahrab-i makfüf-i mahzunff(--.|-..|.--.|-.-) and relies on the rhyme $-\bar{a}$ and the radif kunad 'he/she does, makes, etc..' It is preserved only in a small number of manuscripts. ${ }^{18}$
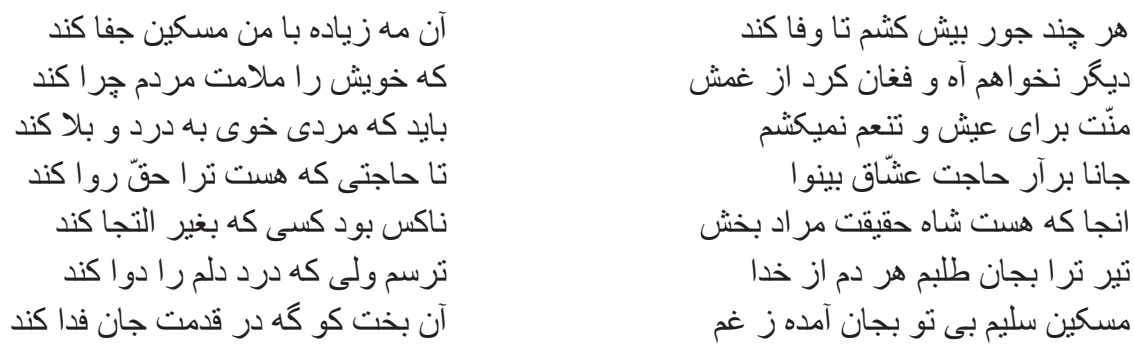

As in the previous case the initial poem in the paraphrase network was a panegyric, a short qiț $a$ written by Hāqānī (d. ca.1199) (Hāqānī 1346/1967: 849). Hāqānīs poem composed in the second person singular is dedicated to the Eldigüzid Muzaffar al-Dīn Qizil Arslān (1186-1191) and its main message wrapped up in elaborately worded praise, was to call the ruler's attention to the poet's divan.

Anvarī (d. ca. 1169) retained the formal framework and composed a lyric ghazal relying on the metre, rhyme and radîf combination seen in Huāqānī's qiț'a (Anvarī 1364/1985: 503). Except for the shared framework and a rhyming word (vafā 'faithfulness') there is no connection between Anvarîs love poem and the '- $\bar{a}$ kunad' poem of Hāfiz composed in a moralising rindāna tone (Hāfiz 1382/2003: 154-155). ${ }^{19}$ A heading preceding Navāyỉs poem in his divan clearly shows that

18 AE ff. 38a-b; Amasya ff. 19a-b; IU929 f. 26a; IU1331 f. 41a; Jerusalem f. 28b; Majlis13392 ff. 49a-b; Majlis21013 pp. 134-135.

19 Dìvān-i kāmil-i Hāấz, 154-155. Kulliyāt-i Ahlī-yi Šìrāzī, 10-13. 
his javāb was meant as a poetic reply to the ghazal of Hăfiz (Navāyī 1342/1963: 145-146). It seems that the ghazal of Hāfiz initiated another paraphrase network that consists of poems relying on the same metre and rhyme but using a slightly different radif. Instead of kunad 'he/she does', the third person singular of the present form of the verb kardan 'to do', its plural, kunand 'they do' is applied. As a line in Navāyìs poem indicates, the signifying universe of the two paraphrase networks had melted by the second half of the $15^{\text {th }}$ century and elements present in the mundus significans of one of them could be used in poems belonging to the other. The first mișra ${ }^{c}$ in Navāyîs ghazal focusing on the poetical potential inherent in the combination of two concepts, $v a^{\prime} d a$ 'promise' and vafā 'faithfulness', was clearly conceived under the influence of Kātibì's opening couplet (Kātibī 1382/2003: 85).

Navāyī Ia.

$V a^{c} d a$ kunad vafā va bi-vac da vafā kunad

$\mathrm{He} / \mathrm{She}$ promises faithfulness and he/she keeps his/her promises

Kātibī I.

Zulf va ruh-at ču vacda-yi javr u jafā kunand

$\bar{A} n v a^{c} d a$ ham huš ast či bāšad vafä kunand

Your plaits and face promise torment and pain

The promise [itself] is lovely how nice it could be when it's kept

Hāmidī also joined the line of poets who composed an '-ā kunad' poem in mużāri' (Ertaylan 1949: 384). Though wine, a key element of Hāfiẓ’s piece, makes its appearance in the last couplet Hāmidì's poem is closer to the 'āšiqāna mood of Anvarīs ghazal that is totally devoid of rindāna elements praising wine as an entheogen. Wine does not appear in Selīm's ghazal either. But this is not the only common feature Selim's and Anvarîs ghazal share. Selim's matta' contains several hints like the phrase at the beginning of the first $m i s r \bar{a}^{c}$ and the pair of rhyming words that suggests the influence of Anvarìs couplet.

Selim I.

Har čand jaur-i bǐš kašam tā VAFĀ KUNAD

Ān mah ziyāda bā man-i miskīn jafā kunad

[It doesn't matter] however much torture I tolerate [hoping] that he/she will be faithful

That moon [faced one] torments me the wretched one all the more

Anvarī I.

Harč ar jafā bi-jāy-i man ān bī-VAFĀ KUNAD

$\bar{A} \mathbf{n}-r a ̄$ vafā šumāram agar či jafā kunad

If that faithless one torments someone else instead of me

I count this as an act of faithfulness though it torments me.

Beside the apparent inter-textual allusions to Anvarī's poem Selīm's ghazal contains another couplet that contains more subtle allusions to the matla' of Hāfiż's '-ä kunad' ghazal. 
Selīm IV.

Jānā bar ār ḥājat-i 'uššāq-i bì-navā

Tà hạajatī ki hast tu-rā HAQ ravā kunad

Darling fulfi the needs of [your] helpless lovers

[If you wish] God to satisfy the needs you have.

\section{Hāfiz I.}

\section{Gar may furūš ḥājat-i rindān ravā kunad}

İZAD gunah bi-bahšad u daf'-i bala kunad

If the wine-seller satisfies the needs of the vagabonds,

God forgives [all] sins and averts trouble.

The basic idea underlying both couplets is that if someone satisfies the needs of the destitute, God will grant his wishes. Though the two couplets are seemingly very different, there are many similarities between the two bayts and there is a level of interpretation where Selim's couplet can be seen as a paraphrased version of Hāfiż's lines.

In the context of rindāna ghazals rinds are people on a spiritual quest trying to attain a personal experience of God ( $\bar{I} z a d)$. Lovers (' $u \check{s}$ šāq) in Selīm's ghazal can be of a very similar flock, people who are not in love with another human being ('ašq-i majāzī). Their love is real love ('ašq-i haqīqi) directed towards the Ultimate Truth (Haq). The difference between the two couplets lies in the poets' different perspectives. While Hāfiẓ's statement is a general one claiming that an action helping friends of God to get closer to their goals earns God's approval and results in a blissful state, Selim's bayt put into the context of a love poem is more specific and promises heavenly reward to the beloved if he/she takes notice of his/her lovers.

Except for these inter-textual allusions Selīm's '-ā kunad' poem does not contain further textual references to any of the poems of the paraphrase network. The case of this ghazal is very similar to the previous one. The not too difficult metre, the set of rhyming words that have many possibilities for semantic bonding and the easy to use radif guarantee that the poet's imagination can freely and creatively work within these very wide boundaries.

As a conclusion of the analyses hitherto done it is possible to conclude that Selim's poetic replies connected to ghazals of Hāfiz are emulations and not simple slavish imitations. Though the four cases are different because in the first two cases Selim targeted two well-known poems written by an acknowledged poet and in the third and fourth case his models were lesser known ghazals, Selīm aplied a very similar strategy in all the cases. Using the space allowed by the poetical framework, he tried to go round the problem. He kept a distance from his models and instead of trying to compose a direct reply to them, he turned to the signifying universe of the paraphrase networks containing his models and used whatever was available there. He picked several of the poetic building stones of some choice elements of these networks, reworked, reshaped them according to his own taste, added his own ideas and out of this mixture created his own poems. The results of his efforts are javābs that are typical emulation poems. They are in constant discourse with the tradition that inspired them and at the same time are refreshingly unique and original. As far as the artistic value of Selim's ghazals are concerned it would be most befitting to conclude the present paper with T. S. Eliot's thoughts on tradition and individual talent.

'One of the facts that might come to light ... is our tendency to insist, when we praise a poet upon those aspects of his work in which he least resembles anyone else. In these aspects or parts 
of his work we pretend to find what is individual, what is the peculiar essence of the man. We dwell with satisfaction upon the poet's difference from his predecessors, especially his immediate predecessors; endeavour to find something that can be isolated in order to be enjoyed. Whereas if we approach a poet without this prejudice we shall often find that not only the best but the most individual parts of his work may be those in which the dead poets, his ancestors, assert their immortality most vigorously' (Eliot 1982: 36).

Open Access. This is an open-access article distributed under the terms of the Creative Commons Attribution 4.0 International License (https://creativecommons.org/licenses/by/4.0), which permits unrestricted use, distribution, and reproduction in any medium, provided the original author and source are credited, a link to the CC License is provided, and changes - if any - are indicated. (SID_1)

\section{REFERENCES}

\section{Primary sources}

ABū IsHĀQ Hallāj-i Šīrāzī 1302/1885. Dīvān-i aț ima. Qustantinīya: Čāphānayi Abū Żiyā.

ĀHī. Dìvān-i Āhì. Süleymaniye Yazma Eser Kütüphanesi, Esad Efendi 3422, ff. 136b-155a.

Ahlī 1344/1965. Kulliyāt-i aš ār-i Maulānā Ahlī-yi Šìrāzī. Bi-kūšiš-i Hāmid RabbĀNī. Tihrān: Kitābhāna-yi Sanā'ì.

Amīr Husrau 1361/1982. Dìvān-i kāmil-i Amīr Husrau Dihlavī. Bi-tașhịị̂i Sa īid Nafīsī. Bi-kūšišs-i M. DARVİŠ. Tihrān: Intišāāāt-i Jāvidān.

Anvarī 1364/1985. Dīvān-i Anvarì. Bā muqaddima va tașhịḥ va maqābila-yi hašt nusḩa. Bi-kūšiš-i Sa'īd

Nafīsī. Tihrān: Intišārāt-i Pīrūz-Sikka.

Ašraf. Dīvān-i Ašraf. Süleymaniye Yazma Eser Kütüphanesi, Fatih 3777.

Auhadī Marāgà'ī 1376/1997. Dīvān-i Kāmil-i Auhadī Marāğga'ī. Tihrān: Intišārāt-i Pīšrau.

Brockhaus, Hermann 1954. Die Lieder des Hafis. Persisch mit dem Commentare des Sudi. Leipzig: F. A. Brockhaus.

ButLer, Haidd Edgworth (ed./trans.) 1996. The Institution Oratoria of Quintilian with an English Translation. Cambridge: Harvard University Press.

Dìvān-i Sulțān Selìm. İstanbul Ünivesitesi Nadir Eserler Kütüphanesi, FY 1330.

ErTAYlan, İsmail Hikmet 1948. Külliyât-i Dîvân-i Kabulî. İstanbul: İstanbul Üniversitesi Edebiyat Fakültesi. ErTaylan, İsmail Hikmet 1949. Külliyāt-i Dìvān-i Hāmidì. İstanbul: Millî Eğitim Basımevi.

FATTĀhịī Nīšāpūrī (Sībak) 1385/2006. Dìvān-i gazaliyāt va rubā'iyāt. Bi-ihtimām-i Mahdī MuhaQQQAQ va Kabrī Bustān-šīeīn. Tihrān: Anjuman-i Asar va Mafakhir-i Farhangi.

Ḥāfiz 1382/2003. Dīvān-i kāmil-i Ḥāfiz. Bi-ihtimām-i Muhammad QAzvīnī va Qāsim-i Ġanī. Tihrān: Intišārāt-i Țahūrī.

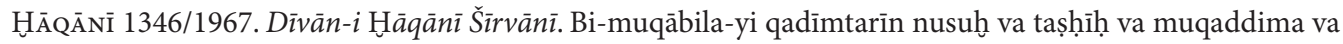
taclīqāt. Bi-kūšiš-i Żiyā al-Dīn SAJJĀDī. Tihrān: Kitābfurūšī-yi Zavvār.

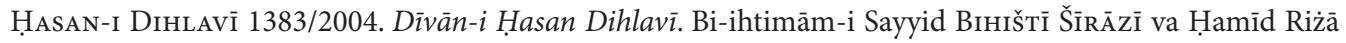

QııIČḩ̄̄iñ. Tihrān: Anjuman-i Āsār va Mafāhar-i Farhangī.

Haydar Haravī, Dìvān. Upsala Univ. Bibliothek, Nova 389. 


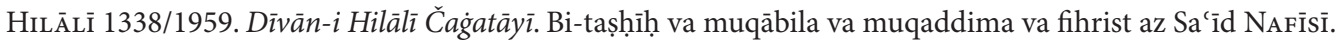

Tihrān: Kitābhāna-yi Sanā'̄̄.

JĀMī, Nūr al-Dīn 'Abd al-Raḥmān b. Aḥmed 1378/1999. Dìvān-i Jāmī. 2 vols. Muqaddima va taṣhịḥ 'Alāhān AfṣAḥ̂̄ĀD. Tihrān: Mīrās-i maktūb.

KamĀL-I HujAndī 1372/1993. Dīvān-i Kamāl-i Huujandī. Taḥṣịh-i Ahmad Karamī. Tihrān: Našriyāt-i Mā.

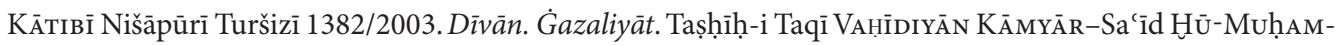
MAdī ḤAYRĀBĀDĪ and Mujtabā JaVĀDİ-NiYā. Mašhad: Bunyād-i Pažūhašhā-yi Islāmī.

Kınalızade Hasan Çelebi 1989. Tezkiretüşs-şuara. II. Haz. İbrahim Kutluk. Ankara: Türk Tarih Kurumu.

LA'ĀLì. Dìvān-i La'àlī. Süleymaniye Yazma Eser Kütüphanesi, Esad Efendi 3422, ff. 234b-246a.

LATîFî 2000. Tezkiretüşs-Şua'arâ ve Tabsiratün-Nuzamâ. İnceleme-Metin. Haz. Rıdvan Canım. Ankara: Atatürk Kültür Merkezi Baskanlığı.

MaǴribĩ 1372/1993. Dìvān-i Muhammad Šìrīn Mağribì. Bi-tasḥịh va ihtimām-i Liūnard Lūizon (Leonard Lewisohn). London-Tihrān: Dānišgāh-i Makgill-Dānišgāh-i Tihrān.

NĀṣır-I HuUsrau 1357/1978. Dīvān-i aš‘ ār-i ḥakīm Nāṣir-i Husrau. Bi-ihtimām-i Mujtabā Mīnovĩ va Mahdī MuHaqqiq. Tihrān: Mu’assasa-yi Muțāla āt-i Islāmī-yi Dānišgāh-i MakGīl.

NAvĀYİ, Amīr 'Alī-šīr 'Fānī'1342/1963. Dìvān. Bi-sa 'ī va ihtimām-i Rukn al-Dīn HumĀYūN-FARruH. Tehran: Kitābhāna-yi Ibn Sīnā.

Niz̄̄eì QuHistānī 1371/1992. Dìvān-i Hakīm Nizārī Quhistānī bar asās-i dah nusha. Bi-jam` va tadvīn va muqābila va taṣhịḥ va taḥšiya va ta 'līq va dībāča-yi Muẓāhir MuṢAffā. Tihrān: Intišārāt-i 'Ilmī.

QĀRİ-I YAZDī 1303/1886. Dìvān-i albisa. Qustantinīya: Maṭba'a-yi Abū Żiyā.

RŪMĪ, Maulānā Jalāl al-Dīn 1388/2009. Kulliyāt-i Šams-i Tabrīz. Muțābiq bā nusha-yi tașhīḥ šuda-yi Badīc al-Zamān FirūZanfar. Tihrān: Intišārāt-i Payām-i 'Adālat.

SA 'Dī 1385/2006. Kulliyāt-i Sa'dī. Bi-tașhịhh-i Muhammad 'Alī Furūg̣ī. Tihrān: Intišārāt-i Hurmus.

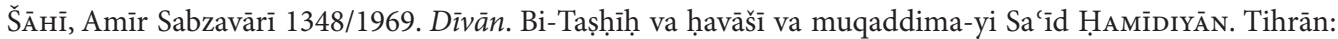
Intišārāt-i Ibn Sīnā.

SAlmān SĀvajī 1371/1992. Dìvān-i Salmān Sāvajī. Bā muqaddima va taṣhịḥ̣-i Abū al-Qasim Ḥ̂̄LAt. Tihrān: Našriyāt-i Mā.

Selìm 1904. Dìvān-i balāgat 'unvān-i sulțān Salìm Ȟān-i avval. Bi-ihtimām-i Pāūl Hūrn (Hrsg. von Paul HORN). Berlin: Mațba'a-yi davlatī.

Solmaz Süleyman 2005. Ahdî ve Gülşen-i Şưcarâsı. (İnceleme - Metin). Ankara: Atatürk Kültür Merkezi Başkanlığı.

SūDī 1366/1987. Šarḥ-i Sūdī bar Hạfiz. 4 vols. Tarjuma-yi 'Ismat SATTĀRZĀDA. Tihrān: Intišārāt-i ZarrīnIntišārāt-i Nigāh.

Sup, Shin Yang 1995: Dîvân-i Mas' ûd-i Kummî. Doktora Tezi. İstanbul: İstanbul Üniversitesi.

\section{Secondary sources}

AtEş, Ahmet 1968. İstanbul Kütüphanelerinde Farsça Manzum Eserler. Üniversite ve Nuruosmaniye Kütüphaneleri [Poetical Works in Persian Preserved in Libraries in Istanbul. The University Library and the Nuruosmaniye Collection]. İstanbul: Devlet Kitapları.

BAĞC1, Serpil, Filiz ÇAĞman, Günsel RendA, and Zeren TANınd1 2010. Ottoman Painting. Ankara: Republic of Turkey, Ministry of Culture and Tourism, Publications-Banks Association of Turkey.

Eцiot, Thomas Stearns 1982. 'Tradition and the Individual Talent.' Perspecta 19: 36-42.

Hillmann, Michael C. 1975. 'Hafiz's “Turk of Shiraz” Again.' Iranian Studies 8/3: 164-182. 
Kuru, Selim S. 2012. 'The Literature of Rum: The Making of a Literary Tradition: (1450-1600)'. In: Suraiya N. Faroqhi and Kate Fleet (eds.) The Cambridge History of Turkey. Vol. 2. The Ottoman Empire as a World Power 1453-1603. Cambridge: Cambridge University Press, 548-592.

Meisami, Julie Scott 2010. 'A Life in Poetry: Hāfiz's First Ghazal'. In: Franklin Lewis and Sunil Sharma (eds.) Necklace of the Pleiades. 24 Essays on Persian Literature, Culture and Religion. Leiden: Leiden University Press, 163-181.

PÉRI Benedek 2010. 'Szelim szultán perzsa gazaljai I. Az első megközelítés. (The Persian ghazals of Sultan Selim I. A First Approach).' In: DÉvéNyi Kinga (szerk.) Varietas Delectat. Tanulmányok Kégl Sándor emlékére. Budapest: Magyar Tudományos Akadémia Könyvtára, 21-45.

PÉRI Benedek 2015a.' 'I. Szelim szultán kiadatlan perzsa versei I (Unpublished ghazals by Yavuz sultan Selim. Part I.).' Keletkutatás 2015 tavasz: 115-138.

PÉri Benedek 2015b. 'I. Szelim szultán kiadatlan perzsa versei II. (Unpublished Persian poems of Sultan Selim I. Part 2.).' Keletkutatás 2015 ösz: 113-130.

PÉRI Benedek 2017. 'From Istāmbōl's throne a mighty host to Irān guided I;/Sunken deep in blood of shame I made the Golden Heads to lie': Yavuz Sultan Selim's Persian poetry in the light of the Ottoman-Safavid propaganda war'. Archivum Ottomanicum 34: 183-192.

PÉRI Benedek 2018. ' «...beklerüz». An Ottoman Paraphrase (nazīre) Network from the $16^{\text {th }}$ Century.' In: Christiane Czygan and Stephan Conermann (eds.) An Iridescent Device: Premodern Ottoman Poetry. Göttingen: V\&R Unipress, 147-180.

PÉRI Benedek 2018. 'Mīr 'Alī-Šīr Navāyī and the first ghazal of Hāfiz.' In: Shuhrat Sirojiddinov (ed.) "Alisher Navoiy va XXI asr” mavzuidagi Respublika ilmiy-nazariy anjumani materiallari. Toshkent: Tamaddun, 176-183.

YĀRŠĀṬır, Iḥsān 1334/1955. Ši'r-i Fārsi dar 'ahd-i Šāhruh [Persian Poetry in the Age of Shahruh]. Tihrān: Dānišgāh-i Tihrān.

Zıpoli, Riccardo 1993. The Technique of the Ğawāb. Replies by Nawà̄ carina. 